\title{
Employee Engagement at Victory Visions Software Development, Chennai
}

\author{
Magdalene Peter, Fabiyola Kavitha, Susmita
}

\begin{abstract}
Industrial revolution occurred in England, marked significant change in history of mankind. It was a revolution in industry, commerce and means of communication. The Industrial Revolution was totally helpful to the advancement of the world from the 1800s right to show day. Penances were made which permitted mechanical progressions during the Industrial Revolution, which thus, made satisfaction, life openings, and a generally speaking, unmistakable improvement of life.
\end{abstract}

Keywords: Industrial Revolutions, Mechanical Progresions

\section{INTRODUCTION}

Mechanical unrest happened in England, checked critical change in history of humankind. It was an insurgency in industry, trade and methods for correspondence. [1],[3],[5] The Industrial Revolution was totally valuable to the advancement of the world from the 1800 s right to introduce day. Penances were made which permitted mechanical headways during the Industrial Revolution, which thus, made satisfaction, life openings, and a generally, clear enhancement of life. [2 ],[4],[6]

The reason for the examination on worker inclusion in the board and cooperation is to look at the three variables: the executives synergistic, authority support, and between group relationship impact on gathering strength and group attachment; to test the impact of gathering power and group union on hierarchical adequacy by means of a directing impact of authoritative correspondence. [7], [9] ,[11] Besides, the key research questions are do the three components identify with gathering power and group union; how gathering intensity and group union effect on hierarchical viability; do the gathering strength and group union effect on authoritative adequacy by means of a directing impact of hierarchical correspondence. [8], [10],[12]

The establishment of good cooperation is having a mutual promise to basic destinations. Without this, every single other type of group building will have a constrained effect. [13], [15],[17] Along these lines, before utilizing any group

\footnotetext{
Revised Manuscript Received on July 22, 2019.

Ms. Magdalene Peter, Department of MBA, Bharath Institute of Higher Education and Research, Chennai, India.

Email: magdalene.bsb@gmail.com

Dr Fabiyola Kavitha, Department of MBA, Bharath Institute of Higher Education and Research, Chennai, India.

Email: fabiyolakavitha@gmail.com

Susmita, Department of MBA, Bharath Institute of Higher Education and Research, Chennai, India.

Email: susmita@gmail.com
}

building activities and exercises, or taking a gander at connections in the group, or setting out on different types of group building, you have to set up this establishment of shared responsibility by:

\section{Clarifying the group objectives}

Building proprietorship and duty to those objectives over the group

$\square$ Identifying any issues which restrain the group from arriving at their objectives [14], [16],[18]

Addressing those issues, expelling the inhibitors and along these lines empowering the objectives to be accomplished

\section{OBJECTIVES}

$>$ To get an insight knowledge about the working of the organization.

$>$ To improve the quality of working life by allowing the workers to study the extent of greater influence and involvement of employees in decision making of a work and the satisfaction obtained from work.

$>$ To study the mutual co-operation of employees and employer in the organization. [19], [21],[23]

$>$ To study the effectiveness of decision making system at Victory Visions Software Development.

$>$ To study the opinion of employees towards job satisfaction and workers participation management.

\section{RESULTS}

To get an understanding information about the working of the association.

$>$ To improve the nature of working life by enabling the laborers to think about the degree of more prominent impact and association of representatives in basic leadership of a work and the fulfillment got from work. [20], [22], [24]

$>$ To study the shared co-activity of representatives and boss in the association.

$>$ To study the adequacy of basic leadership framework at Victory Visions Software Development.

$>$ To study the sentiment of representatives towards occupation fulfillment and laborers support the board.

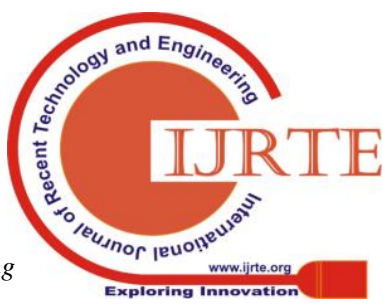




\section{DISCUSSIONS}

To get an understanding learning about the working of the association.

$>$ To improve the nature of working life by enabling the laborers to ponder the degree of more noteworthy impact and contribution of representatives in basic leadership of a work and the fulfillment got from work.

$>$ To study the common co-activity of representatives and boss in the association.

$>$ To study the viability of basic leadership framework at Victory Visions Software Development.

$>$ To study the feeling of representatives towards occupation fulfillment and laborers cooperation the board. [25], [27], [29]

\section{V.CONCLUSION}

The Study was directed for Victory Visions, to think about the worker commitment. The report at last intends to state that the administration should take measures for successful working of board of trustees. The administration should execute the laborers proposal as fast as workable for their disability. [26], [28], [30] This has empowered the plant to make remedial move any place vital and to fortify the current board. There is an expanded effectiveness of people and gathering of works and thereby to by and large increments in the profitability of the Victory Visions. [31], [33]

\section{REFERENCES}

1) BharthVajan R., Ramachandran S.,Psychographic dimensions of training,2016,International Journal of Pharmacy and Technology,V-8,I-4,P-23727-23729

2) Balakrishnan P., Bharthvajan R.,A study on human resource planning in hospitals in Chennai City,2014,International Journal of Applied Engineering Research,V-9,I-22,P-7503-7507

3) Priyadarsini P., Bharthvajan R.,Role of emotional intelligence training programme in reducing the stress of the nurses,2014,International Journal of Applied Engineering Research,V-9,I-22,P-7411-7421

4) Kerinab Beenu G., Bharthvajan R.,Empirical analysis on the cosmetic buying behavior of young women in South India,2014,International Journal of Applied Engineering Research,V-9,I-22,P-7361-7366

5) Balakrishnan P., Bharthvajan R.,Whistling in the wind,2014,International Journal of Applied Engineering Research,V-9,I-22,P-7586-7593

6) Krishnan B., Peter M.,Health hazards of Indian Bpo employee-an alarming issue,2014,International Journal of Applied Engineering Research,V-9,I-22,P-7336-7341

7) Kerinab Beenu G.H., Peter M.,Role of insurance in economic development,2014,International Journal of Applied Engineering Research,V-9,I-22,P-7532-7539

8) Balakrishnan P., Peter M., Priyadarsini P.,Efficiency of safety measures for wellbeing of employees in manufacturing industry,2014,International Journal of Applied Engineering Research,V-9,I-22,P-7376-7382

9) Anbarasi M., Praveen Kumar S.,Online sales promotions of herbal products and its effectiveness towards tanisha.com,2019,Indian Journal of Public Health Research and Development,V-10,I-1,P-195-200

10) Anbarasi M., Praveen Kumar S.,Various online marketing and promotions strategies to improve the validation towards the organic products in the pharmaceutical sectors, 2019,Indian Journal of Public Health Research and Development,V-10,I-1,P-263-269

11) Loganathan R., Praveen Kumar S.,Grievance handling a key factor for solving issues of employees in an organization,2014,International Journal of Applied Engineering Research,V-9,I-22,P-7483-7491

12) Loganathan R., Praveen Kumar S.,Study on preference of private label brands in super and Hypermarkets,2014,International Journal of Applied Engineering Research,V-9,I-22,P-7327-7335
13) Smitha M., Praveen Kumar S.,Understanding stress and its managementamong the nurses in Chennai city,2014,International Journal of Applied Engineering Research,V-9,I-22,P-7560-7565

14) Kerinab Beenu G.H., Praveen Kumar S.,A study on the investment behavior of Chennai investors in mutual fund schemes,2014,International Journal of Applied Engineering Research,V-9,I-22,P-7520-7525

15) Loganathan R., Praveen Kumar S.,Retention strategies key for organizational productivity,2014,International Journal of Applied Engineering Research,V-9,I-22,P-7443-7447

16) Pavithra J., Ganesan M., Brindha G.,State wise analysis of microfinance sector in India,2016, International Journal of Pharmacy and Technology,V-8,I-4,P-23417-23432

17) Pavithra J., Ganesan M.,A comparative study on microfinance in India and abroad,2016,International Journal of Applied Business and Economic Research,V-14,I-8,P-5471-5476

18) Pavithra J., Ganesan M.,A study on awareness and impact of micro-financial schemes,2016,International Journal of Applied Business and Economic Research,V-14,I-8,P-5449-5460

19) Senthilmurugan P., Pavithra J.,Consumer preference towards organised retailing with reference to Big Bazaar,2014,International Journal of Applied Engineering Research,V-9,I-22,P-7469-7475

20) Senthilmurugan P., Pavithra J.,Implication of social media marketing in growing healthcare industry,2014,International Journal of Applied Engineering Research,V-9,I-22,P-7448-7456

21) Loganathan R., Pavithra J.,Consumer perception towards private label brand over other brands in super markets and hypermarkets,2014,International Journal of Applied Engineering Research,V-9,I-22,P-7355-7360

22) Kerinab Beenu G., Pavithra J.,Tradeâ€"off between liquidity and profitability in logistics industry,2014,International Journal of Applied Engineering Research,V-9,I-22,P-7398-7401

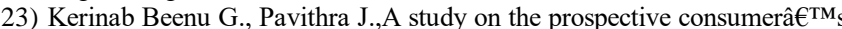
perception towards utility cars in Chennai city,2014,International Journal of Applied Engineering Research,V-9,I-22,P-7526-7531

24) Pavithra J., Dilli Babu P., Ambuli T.V.,A study on budgetary control at Maruti Service Masters, Chennai,2014,International Journal of Applied Business and Economic Research,V-12,I-2,P-151-161

25) Pavithra J., Dilli Babu P., Ambuli T.V.,A study on customer satisfaction of retro Garments Pvt Ltd, Chennai,2014,International Journal of Applied Business and Economic Research,V-12,I-2,P-381-391

26) Kerinab Beenu G.H., Pavithra J., Senthilmurugan P.,A study on the influence of promotional activities for TATA ARIA among consumers in Chennai,2014,International Journal of Applied Engineering Research,V-9,I-22,P-7572-7578

27) Vijayaragavan S.P.,An investigative expert that's general FBG sensors,International Journal of Mechanical Engineering and Technology,V-8,I-8,PP-1500-1505,Y-2017

28) Vijayaragavan S.P.,Equalization routing protocol for Wi-Fi sensor strategy,International Journal of Mechanical Engineering and Technology,V-8,I-8,PP-1662-1666,Y-2017

29) Karthik B., Kiran Kumar T.V.U., Vijayaragavan P., Bharath Kumaran E.,Design of a digital PLL using 0.35 $\hat{\mathrm{I}}^{1 / 4 \mathrm{~m}}$ CMOS technology,Middle East Journal of Scientific Research,V-18,I-12,PP-1803-1806,Y-2013

30) Kanniga E., Selvaramarathnam K., Sundararajan M.,Kandigital bike operating system,Middle - East Journal of Scientific Research,V

31) Jasmin M., Vigneshwaran T., Beulah Hemalatha S.,Design of power aware on chip embedded memory based FSM encoding in FPGA,International Journal of Applied Engineering Research,V-10,I-2,PP-4487-4496,Y-2015

32) Jasmin M.,Optimization techniques for low power VLSI circuits,Middle East Journal of Scientific Research,V-20,I-9,PP-1082-1087,Y-2014

33) Jasmin M., Vigneswaran T.,Fuzzy controller for error control of on - Chip communication,2017 International Conference on Algorithms, Methodology, Models and Applications in Emerging Technologies, ICAMMAET 2017,V-2017-January,I-,PP-1-5,Y-2017 


\section{AUTHORS PROFILE}

Ms. Magdalene Peter Assistant Professor, Department of MBA, Bharath Institute of Higher Education and Research, Chennai, India.

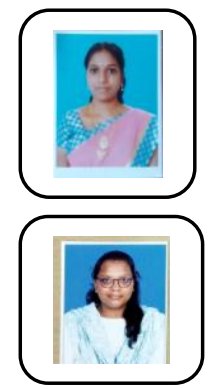

Dr Fabiyola Kavitha Associate Professor, Department of MBA, Bharath Institute of Higher Education and Research, Chennai, India.

Susmita Student, Department of MBA, Bharath Institute of Higher Education and Research, Chennai, India. 